Cveta Razdevšek Pučko, PhD

Jože Rugelj, PhD

University of Ljubljana, Faculty of Education

\title{
The Didactic Value of a Web Log in the First Educational Period of Primary School
}

Summary: The Internet undoubtedly represents a technological invention affecting the way people communicate, access information, and gain knowledge. For the younger generations, who grew up and live with the Internet, it is of paramount importance that it properly supplements and aids the classical education practice. This paper presents selected results and discusses experiences obtained in a comprehensive action research study dealing with the investigation of opportunities for the application of a web log in the first educational period of primary school. The main purpose of educational innovation is to encourage pupils to become active participants and creators of their own social learning environment, where knowledge is represented and shared in the form of various authentic materials and reflections. The results of the study reveal that a computer with the appropriate educational software, and especially a web log, can be applied as an effective teaching and motivational tool to help achieve curriculum objectives, contributes to the development of digital literacy, and supports the acquisition of reflection skills. Competent use of modern educational technologies therefore stimulates new ways of thinking, while the acquired knowledge not only helps achieve the educational objectives, but also breaks new ground for active participation in the information society.

Key words: action research, weblog, motivation, digital literacy, reflection.

\section{Introduction}

In a postmodern, globally developed society, lifestyles are drastically changing under the influence of technological advancements. Rapid soci-

1 spela.kuncic@gmail.com etal changes together with findings of cognitive science call for the modernization of the education system, not only to improve the quality of the educational process by using a wide range of information and communication technologies (ICT), but also to introduce a variety of learning and organization- 
al forms. Moreover, they allow more flexibility in terms of time, space, and content of the education. New educational paradigms based mainly on the use of ICT allow teachers to be more efficient and achieve better quality of work, as well as stimulate them towards continuous professional development and the adoption of new teaching competencies.

Action research is undoubtedly an indispensable approach to value the effect and consequences of changes introduced in the education. This qualitative research method specifically emphasizes the active role of a teacher as a researcher who implements and evaluates changes that lead to better understanding of current education practice, and consequently have the potential to improve the quality of teaching process (Kemmis and McTaggart, 1991; Vogrinc and Valenčič Zuljan, 2009). In this respect, some more recent strategies addressing educational changes often expose the importance and capabilities of modern learning technologies for education (Carrington and Robinson, 2009; Davies and Merchant, 2009; Roblyer, 2006). Among those is also an innovation in the form of a web log supporting learning activities in the first educational period of primary school.

\section{Definition of a web log}

Modern means of learning in the form of a web log attributes within the scope of e-learning. It represents a way for the implementation of various forms of teaching and learning that are supported using ICT, electronic media, applications, and services to improve the educational process (Kigozi Kahiigi et al., 2008). This approach does not exclude traditional forms and methods of education, but is primarily used as a complement. Such grouping is often called "blended learning", which combines traditional teaching methods and modern media formats for effective learning experience (Lapuh Bele and Rugelj, 2007).
In the framework of the action research, we defined pedagogical innovation in the form of a web $\log$ as a synthesis of two forms: a presentation portfolio and an electronic portfolio.

\section{Presentation Portfolio}

A presentation portfolio is the collection of learning achievements chosen by pupils, according to their own criteria. It is created with the aim of representing the process of learning and the achievements within a certain period. This collection follows and represents the learning process, its results, skills, and the pupil's attitudes about schoolwork (Danielson and Abrutyn, 1997). A portfolio is not and should not be just a folder for keeping all kinds of documents, but rather a selection of documents with a pupil's reflection about: (i) what I am doing and how I feel about doing it; (ii) is my performance congruent with my expectations; (iii) how do I assess the results of my work, and (iv) what are my next learning goals. To be able to select the representative documents and express the reflections about their own work, pupils should develop specific vocabulary and skills. To achieve these, certain time and relevant exercises are needed.

Implementation of a portfolio is very important for all participants in educational process. $\mathrm{Pu}$ pils can show the results of their work and be proud of good achievements. They themselves can follow their own development and plan their future work as well as the corrections and changes for its improvement. They are involved in assessment procedures, and in this way become more responsible and independent. This is a path towards lifelong learning without external control and pressure. In reflecting on their own work, they see the difference between process and result, and are able to evaluate their own strengths and weaknesses (Razdevšek Pučko, 1997). The teacher has better opportunities to become aware of the individual characteristics of pupils, to follow not only results, but also the learning process, and at the same time dispose with the informa- 
tion needed for formative feedback. The selection of a child's work also gives parents the opportunity to follow the learning development of their child. They are able to see the results of concrete learning actions, and are able to cooperate in some activities. In this way, they get better insight in schoolwork. An important result is also better communication between teacher and parents, as they both have the same information about a pupil's schoolwork (Reynolds, 2000).

\section{Electronic Portfolio}

In the new millennium, especially in the Anglo-Saxon world, an idea of using an electronic portfolio in education began to emerge. It is a pooling of ideas of a classic portfolio and the use of ICT, which replaces paper-based artefacts by collecting and displaying the selected digitized content on the World Wide Web. An electronic portfolio is a collection of authentic materials containing reflections and demonstrating what an individual or a group learned in a certain period. The electronic version is usually prepared for the demonstration of results to the public. ICT allows presentation of learning outcomes in the form of text, images, audio, and video content online. Thus, by using virtual links we are telling a story of digital learning that is constantly evolving and improving, is geared towards the individual, and lifelong (Barrett, 2006). It is also important that learning takes place in the creation process and not just from the final product. The digital representation of the knowledge gained, therefore, encourages reflection, an exchange of ideas, and collection of feedbacks (Barrett, 2007; Lorenzo and Ittelson, 2005 Hartnell Young and Morriss, 2007). Since Web 2.0 as the current evolution of the World Wide Web requires a dynamic and active user and the creator of online content, the newly emerged blog services are set by the side of an electronic portfolio in the form of websites. A blog is a chronologically arranged online set of records, which are based on the use of content management systems and allow users to publish various contributions (e.g. text, images, video, and audio) to the pre-prepared site. A blog contains the central part with author's publications called posts and aside-menu with a list of hyperlinks to other web documents or blogs recommended by the author (blog roll). Some authors (Du and Wagner, 2007; Kim, 2008; Davies and Merchant, 2009) mention blogs as a new technology for knowledge sharing. They emphasize their simple construction and use with all the tools needed being freely available. Such "cloud services" also provide users a place to store and publish posts.

A web log for pedagogical work in the first period of primary school is a collection of multimedia products that show what an individual or a group learned in a specified time. It should be noted that the participants in the educational process design, store, and display the web log content in a digital format using ICT. This allows the documentation of the learning process and the publication of articles in a variety of forms and formats, including the form of static web pages, and web formats in the form of a blog. The role of a blog as a narrator presents a new teaching medium, exploiting ICT and the Internet for delivering learning content, and for the publication of academic achievements in the form of a chronological web story. This is particularly interesting and attractive for pupils because they can tell the story of school work through a variety of online publications, thus taking an active part in a society, and enriching their language, speech, and cognitive ability.

\section{Research aims}

The creation and use of a web log together with the inclusion of modern ICT represents a novel approach in the Slovene educational environment. The aim of the action research study presented in this paper was to investigate and introduce a model for its application in the first educational period of primary school. In addition to innovating and assessing the didactic value of a web log as a teaching 
and motivational tool, special attention was paid to the development of digital literacy and reflection skills. In this respect, the present paper presents a brief model for the design and use of a web $\log$, as well as discusses the following question of a comprehensive action research study:

- What is the didactic value of a web log in the first educational period of primary school?

- What learning achievements in the field of digital literacy skills can be gained by the use of a web log?

- What are the advantages and disadvantages of using a web log in the educational process?

\section{Method}

The qualitative action research employed the following two methods: (i) the causal-non-experimental method with the implementation of pedagogical innovation, and (ii) a descriptive method for the presentation of research findings.

The research involved 20 pupils and their parents from one class of a nine-year primary school in Ljubljana, Slovenia. The study spanned over three years of the first educational period (i.e., grade 1 to grade 3), where each year corresponded to one action step. The action steps took a spiral process, each containing planning, action, and assessment of the achieved results (Kemmis and McTaggart, 1991; Vogrinc and Valenčič Zuljan, 2009). The classroom teacher had the role of a teacher researcher and used different methods of qualitative action research. Data relating to the development of pedagogical innovation and its effects were collected by observation, where various field notes and specially designed digital literacy checklists were used. As a supplement, non-standardized questionnaires and non-standardized, semi-structured group interviews were also employed. A document analysis comprised the review of different written resources such as a curriculum of different subjects, lesson plans, teacher's notes, participant's reflection notes, pupil's artefacts, and a web log.

Throughout the period of the pedagogical innovation development all steps have been thoroughly evidenced, with the verification and credibility of research findings assured by the following strategies: a long period of data collection, the use of triangulation, precise planning of the research process, consultations with critical friends, and repeated presentation of findings to the professional public. Signed consent forms have been obtained from parents for pupils' participation in the research study, as well as for the online publication of the artefacts produced by pupils. A computer with appropriate software and access to the Internet was assured for all participants of the study.

\section{Action steps}

Based on the study of existing literature and online resources, initially an outline of research was designed and the necessary conditions for the implementation of the project were provided. The latter consisted of the provision of hardware and software tools, presentation of research to the parents, and obtaining consent for (i) pupils' participation in the research study and (ii) online publication of their products. In connection with the objectives of lessons, we performed demonstration activities for pupils.

\section{First action step}

In the first action step, the integration of ICT in teaching allowed the creation of specific objectives, namely: (i) to disclose the conditions and show the process of making the web log in the form of websites, (ii) to stimulate pupils and their parents to critical reflection on school work, and (iii) to examine the didactical value of the web log.

In the first few months of the school year, we produced a working portfolio containing materials in different formats. As in the process of collecting, 
we accumulated an excessive amount of materials, we reviewed and critically selected them for inclusion in the web log with pupils in a guided reflexive process. We systematically arranged all selected documents in folders by month and by category. We have also decided to divide the produced contents into public (presentation online) and personal parts (pupil's CD-ROM). As we did not want to design a web log purely as storage of data files, we decided to produce a static website as a set of related Hypertext Mark-up Language (HTML) documents. In the production process, we used several specialized software tools. We designed a clear and simple hierarchical structure of web pages; we defined the colour template, and created graphic elements that were simple and adapted to the developmental stage of the pupils. We selected a national academic network service provider ARNES to host our website. All the materials were uploaded to the server by means of the File Transfer Protocol (FTP). Then we published a hyperlink to our web log on a homepage of our school and made a card as a notice to parents.

\section{Second action step}

Audit and evaluation of the first action step have shown open issues and unexplored possibilities of using a web log and computers in the pedagogic process. Therefore, based on the survey results, we designed the objectives of the activities in the second action step, namely: (i) to functionally and substantively upgrade the product, (ii) to develop a vocabulary for pupil reflection, (iii) to expand the use of educational software tools for achieving the goals of instruction and the development of digital litera$c y$, (iv) to verify the achievement of learning objectives in the field of digital literacy, and (v) to analyse the reported advantages and disadvantages of the use of a web log.

The technical aspect of this action step was an upgrade of the existing product's function. The first reason for the upgrade was the intention that all pupils could learn to use the product independently.
Another reason was to simplify the editorial work. We introduced the scripting language JavaScript and the Cascading Style Sheets (CSS) language for stylish templates. CSS defined the design details, while HTML only served for content structuring. With JavaScript scripts, we allow visitors a more interactive experience, as the HTML elements respond to user interaction with a mouse and automatic control of the pop-ups was supported.

An emergent web log and different didactic software tools were exploited in the teaching process as additional means of learning alongside of classical methods used in courses. A web log was updated with ever better and articles that are more interesting initially typed by the parents and class teacher, and later by pupils, demonstrating their newly acquired digital skills. Pupils wrote the first words and sentences and drew pictures with the help of programs for editing text and drawing. The web log still served us as an online class album, but its literary function was getting more and more important. On various occasions, we used a web browser and sent e-mails; pupils were also introduced to instant messaging. It should be emphasised that ICT-supported activities were generally used as a complement to traditional activities and the use of a notebook, and that they were planned and carefully selected. At the end of the school year, we checked with the specially designed checklist of learning objectives (NET 1998, Hyun, 2005) whether the level of the basic achievements of digital literacy was reached.

\section{Third action step}

The rapid development of ICT opens up new questions and suggests new technical and pedagogical challenges that we have integrated in our work during further innovation and research efforts. For the third action step, we defined the following main objectives: (i) to create a web log in a blog format, (ii) to create personal blogs of pupils, and (iii) to explore the advantages and disadvantages of using a web log. 
Based on examples of good practice, we have decided that we are going to use a special system to manage the content of a web log instead of static website in this step. For the hosting provider we chose Edublogs (http://edublogs.org), which is most popular provider in the field of education. It is based on the WordPress content management system, which is a server application for publishing and editing web content, where the user only needs a basic knowledge of computer literacy, without special software. A blog in the function of the web log allows quicker and much easier addition of multimedia content, blog roll, and widgets in a neatly designed website with contributions arranged in chronological order.

As we wanted pupils and parents to be actively involved in the process of blog creation and to follow the trends of modern methods of online communication, we formed the personal blogs of pupils with different content (e.g. texts, drawings, audio, and video clips) on a new website (http://soncki.edublogs.org). Pupils themselves were responsible for product selection, based on analysis and reflections. Since the communication and interaction with other participants is one of the most important features of blogging, pupils and parents were encouraged to co-create the blog by writing reflective comments on individual posts.

\section{Results}

\section{Web log as a teaching tool}

A web log can play the role of online narrator inlearning stories that by means of images and entries presents teaching material, hidden in the form of a chronological story that is created by pupils under a teacher's supervision. As an additional mean of learning in the classroom, it allows us to use numerous published photos and entries as a tool for introductory motivation to implement lessons, or as material for the reinforcement of knowledge.
With this tool, we enable pupils to discover facts, to form verbal descriptions of events, and to share their thoughts, feelings, and new insights through social networking and teamwork when reviewing the blog. With all these activities, they also learn to listen, to speak literary language, and to ask interesting questions. The development of qualitative observation and expression promotes mental processes and pupils get used to drawing conclusions.

\section{Web log as a motivational tool}

A web log can be seen as a strong motivational support for learning, challenging a pupil's internal motivation. Pupils usually do not have previous experiences with this educational tool, which provokes their curiosity as one of the strong natural and internal motivational forms. This novelty stimulates the desire to know more, and so the motivation for learning is strong. For the majority of pupils e-learning attracts their interests, as they are able to connect these activities with their everyday life. Not surprisingly, pupils are mentally and emotionally prepared for learning with the use of a web log. At the beginning, they see it as a game, which gradually becomes one of the most attractive learning tools.

A web log activities are connected with clear, real, and attractive learning goals, representing important learning motivation. Working to achieve these goals, pupils are able to plan, control, and assess their own learning process. In the way they take the responsibility for results, they get the insight into their own capacities; they can change the way and the tempo of working and/or even the goals. They get insight into their own strengths and weaknesses with possibilities of controlling it. Positive results support their positive self-image, connected with enthusiasm and a high level of mental concentration. In the context the fear of making mistakes is reduced, the feeling of being able to fulfil demands strengthens. The result of all these processes leads to 
better learning results and a high level of learning motivation for the next activities.

With creating and using a web log pupils strengthen their feeling of connectedness with their teacher, parents, and with other classmates. In this way, the web log connects the three most important participants in the school learning processes: pupils, parents, and teacher. They work on common project, they are all interested in good results, their work is not limited by the school schedule, and they all strengthen the feelings of partnership. At the same time, that kind of work supports and develops pupil autonomy. As the result of the possibility for autonomous decisions, connected with the web log, pupils develop a high level of responsibility and important competencies, and their schoolwork is more successful.

\section{Web log as a reflection tool}

With the process of selecting the web log entries pupils were stimulated to express short reflections about chosen items. Within the first action step, the reflections were oral, sometimes accompanied with drawings or pictures. At the end of the school year, the method of unfinished sentences was used to provoke pupil reflection. The expressing of it depends on the pupil's level of literacy as well as his/ her competencies to articulate the reflections in the group. As an example, we represent some expressions: New things, which I learned are mathematics, Slovene language, new songs, many things about nature, I learned to write, to read new stories, I learned how to count; I also learned some new sports exercises. I must be more careful about numbers, I should not make mistakes when I am writing on the blackboard; I must exercise reading, as I am not good enough in it. It can be seen that pupils already recognise their strengths and weaknesses; their main problem was how to express it, which is why their reflections are short and simple.

We also use a web log within the second action step for developing the pupils' reflections on their own work. With more exercises, the reflections became more sophisticated, pupils were already able to express and assess their work, and reflections were longer and more complex. Some pupils were already able to recognise and express the reasons for their good or bad work, and they tried to think about the actions for improvement (I must make more exercises, I must be more careful, I should not hurry). With these reflections, pupils not only assess their work, but also took the responsibility for the results.

We can conclude that in the processes of working with a web log and expressing the reflections on their work pupils developed the competencies for independent planning and performing learning actions. They also become more responsible and autonomous in assessing their own performance.

\section{Learning achievements in the field of digital literacy}

Using the hardware: Pupils perceive the computer as an educational tool and an accessory for games. When they used it, they also found that the computer is a tool for searching, processing, presenting, and storing of data. Without any problems they named and used the basic components of the computer and turned it on and off safely.

Using the software: Pupils had to find, use, and close selected didactic programs. For orientation on the computer's desktop, they used icons, the mouse, and keyboard keys. Most pupils have already printed their own products by simply clicking on the printer's icon. After repeated presentation, pupils were able to use the CD/DVD drive independently.

Using services on the Internet: We can not talk about the independent acquisition of information through web browsers because pupils needed some guidance at work. Key obstacles were deficient reading skills and difficulties in reading from a computer screen. Consequently, pupils were not able to recognize essential information from a set of data. Despite the fact that the use of the Internet took place only 
under the teacher's supervision, using specially selected websites, pupils are acquainted with the rules of safe use of the Internet.

Digital literacy: By the end of the school year, pupils have already independently written words, short sentences and stories, using dedicated programs. They were able to transform text style. They have also been successful in painting with the help of a dedicated program, and have demonstrated creative use of the function keys. Despite the gradual presentation and consolidation steps in the storage of products, the majority of pupils were not yet independent in this skill.

Attitudes to ICT: Compliance with the rules for working with a computer and basic knowledge enabled pupils to investigate how to use computers independently for learning and fun. Some pupils have, on their own initiative, borrowed instructional CDs from the library and presented them to their classmates. The majority of pupils still needed assistance in playing or learning when using the computer. Irrespective of the level of digital literacy, pupils showed readiness for collaborative learning and teamwork with ICT support. Despite the expressed motivation and familiarity with the etiquette, they occasionally encountered minor problems with communication in pairs.

\section{Advantages and opportunities of a web log use}

Technical aspects: In comparison to the conventional paper form of a portfolio, a web log allows you to store the results of activities more easily, to update the content in an easy way, more easily utilize its availability, and it can have multimedia contents. When we compare the design and maintenance of the web log in the form of a website with a "web 2.0 blog," we can see that the main advantage of the latter is in easier and faster publishing and updating the content. In addition to textual contributions, a blog allows us to publish photos, maps, charts, and audio and video clips. By means of hyperlinks, it can be connected to other related online resources. Among the most interesting opportunities of blogging is also the possibility of rapid and simple commenting on individual posts.

Pedagogical and psychological aspects: Advantages and opportunities of integration of modern technology into instruction means more permanent motivation to learn, which contributes to the development of positive self-esteem, encourages a process of reflection, develops collaborative learning, has impact on the development of creative and critical thinking, enables social and individual construction of knowledge, and establishes a partnership between teachers and pupils. Participation in a web log design helps pupils to become more responsible and more independent, as they acquire a variety of information that is critically evaluated. Thus, they become digitally literate and prepared for the challenges of life in the information society.

Literacy training: Using a web log means upgrading the traditional process of literacy. Pupils can create and send a contribution themselves, or with the help of adult learn to publish literary and other contributions using ICT. Reading the entries in a web log also provides an interesting and exciting exercise in reading. Independent reviewing of the recommended content introduces pupils to general and digital literacy. Pupils thus transform from a passive role of the online observer into a creative collaborator and commentator who enriches content with their individual entries.

Social aspect: Joint construction, online publication and group use of a web log establishes an enhanced cooperation among classmates and their parents, teachers, and other institutions. All these can tighten interclass coherence and cohesion of the school with the local environment. Learning becomes creative, independent, and spatially related to the social community in which pupils live.

Media education: The inclusion of a web log in teaching is also an opportunity for systematic and targeted training and tolerant discussion of prob- 
lematic issues that we need to point out, especially if we want pupils to ensure a safe and enjoyable entry into the world of modern technologies. Designing a web log in a blog format allows pupils the freedom to express themselves, while offering numerous opportunities for educational talks on how to be considerate and respectful in the adoption and spread of their views and thoughts.

Innovative work of the teacher: Integrating a web log into lessons for teachers is the possibility of action research, discovery and development of new approaches to teaching, the development of digital competences, and an opportunity for networking and presenting their work to the wider community.

\section{Problems of a web log use}

Equipment and access: The construction of a web log requires adequate computer equipment and Internet access. Therefore, if the teacher wants to create it with his/her pupils, he/she has to provide adequate working conditions by herself, or the institution should supply them, where he/she teaches. Some problems can arise because of scheduling of great number of users in a single computer lab. They can be solved if there is a positive school climate and the willingness of teachers and school leaders to act in a flexible way. Furthermore, there are many different providers of web hosting services in many different languages and without any previous experience it is difficult to determine which system will best fit teacher's needs. In the decision process, he/she can use comparative tables about providers available online. However, the final decision has to be made by the teacher who needs to test and check their adequacy.

Confidentiality and privacy: A web log as a class learning resource is distinguished from a common folder to store entries by the fact that it contains reflections, subjective thoughts, and awareness of what we know and what are our weak areas. In this study we ensure confidentiality in the manner that only general and collective reflections were published on the website. Individual reflection and self-assessment at the end of the school year with reflections from families were stored only on the individual pupil's CD.

Digital inequality: This is a phenomenon that is associated with socio-economic status of pupils and their families, and is related to access to a personal computer with an Internet connection. If we want to have this learning resource available to all pupils, we must provide a computer with Internet access at least in the classroom, where learners can use it under the supervision of a teacher. To allow access to all those who cannot use this technology at home, we need to allow access to contents even in the context of consultation hours or parent-teacher meetings. It is also worth mentioning the possibility of accessing such services in libraries and other public "e-points."

Methods of work: We would also like to draw attention to the methodological hazards that may arise in the integration of ICT into teaching. When selecting an overambitious didactic program, a sense of discomfort and incompetence can develop in pupils, which can cause blockages in the field of tracing and understanding the instructions. On the other hand, when the same program is overused, we notice boredom in the pupils who also use this program at home. In recklessly composed pairs who work with the computer, we witness the conflict that may result from either jealousy when working with computers operated and managed only by the dominant pupil. Conflicts can also be the result because of a more pronounced discrepancy between the pupil and the classmate's knowledge, speed, or abilities.

\section{Conclusions}

Education supported by modern ICT offers a new means of knowledge access, and allows the introduction of new teaching and learning forms. The action research presented in this paper has encouraged the development and evaluation of new peda- 
gogical approaches that integrate the use of a web $\log$ in the first period of primary school. Despite the fact that research findings cannot be sufficiently generalized to introduce a new universal theory, it can be concluded that an educational web log represents an innovation, which improves the existing pedagogical practice.

The results of the action research reveal that proper use of modern education technology efficiently complements and improves traditional teaching practice, as well as enables pupils to obtain richer and broader knowledge. It turned out that the rational use of pedagogical innovation can be used as a teaching and motivational tool to help pupils achieve educational objectives, develop digital literacy, and gain reflection skills. Nonetheless, it helps them to become aware of their learning process and growth over time. The research findings suggest possibilities for the successful integration of digital literacy goals in the process of traditional literacy training. However, it has to be respected that some more complex learning goals require longer periods, generally based on the maturity and basic functional literacy of learner. Expert use of modern learning technologies encourages pupils to become active participants and creators of the social learning environment. The latter allows them to perform a variety of authentic tasks, share their knowledge with others, and reflect upon it. Moreover, at the same time they gain basic digital literacy skills required to participate in the information society. This relates and confirms the statements of many authors (Roblyer, 2006; Barrett and Garett, 2009; Du and Wagner, 2007; Hartnell Young and Morriss, 2007; Redecker et al., 2009), who argue that the use of modern teaching technologies aids the process of lifelong learning by providing, on one hand, new means of information access, and on the other hand introduces a variety of ways to live and learn in the information society. There are as well conflicting opinions. Henry and Jones (2006) report that a pupil using computers has worse capabilities to memorize the read content, as they are distracted by graphical and other effects. Additionally to this, Young (2005) warns against plagiarism and the reduced diversity of expressions. Similarly as in other research studies on the use of ICT in the education (Barrett, 2007; Brečko and Vehovar, 2008), the presented results confirm that digital competences of teachers and their affection for the implementation of ICT to teaching process is, besides the availability of the required ICT equipment, essential for the successful adoption of pedagogical and technical innovation. Moreover, it should also be emphasized that the inclusion of modern educational technologies can only be used as a complement to traditional practice. However, despite the limitations, modern tools and services effectively complement classic education certificates by showing an individual's skills, abilities, and competences for lifelong learning.

Analysis of the received feedback from participating pupils and their parents reveals a very positive general opinion for the design, maintenance, and use of the created web log. Pupils have accepted didactic innovation with enthusiasm and recognized the process of joint creation as edutainment, which helped them feel comfortable, proud, and more confident. Besides taking active role in the preparation of a post, they also liked to reflect upon them, which confirmed their understanding of the whole process purpose and suitability of framework to acquire new skills and knowledge. Some pupils even reported their tendency for the design of a personal web log, which they would arbitrarily fill with their own materials, while others thought that it is more fun to create the content together. Contributing parents perceived a web log as an effective tool for the development of functional and digital literacy skills that enable a verbal and visual representation of schoolwork. Its presence has been recognized to stimulate the development of media education and safe use of modern learning technologies, which as well represent an alternative to computer games. They estimated that positive impacts include increased motivation for learning, gained positive self-image, establishment of positive classmate re- 
lationships, and introduction of new modalities for joint work and collaboration. Some also perceived the development of pupils' sense for self-assessment and observation of skills development, which at the same time has a positive association in their attitudes towards school and obligations. An important general observation is also that active participation of pupils heavily depends on the knowledge and willingness of their parents to assist and help them prepare the contributions.
Acquired knowledge and findings together with positive feedback from the participants represent solid grounds for the use of a web log in education, but at the same time calls for further research and development. However, the introduced practice confirms that a web log represents a modern tool and service for displaying and valuing the results of education. It could therefore be used to complement a classical certificate that illustrates the gained learning achievements and digital literacy skills.

\section{References}

- Barrett, H. and Garrett, N. (2009). Online Personal Learning Environments: Structuring Electronic Portfolios for Lifelong and Life Wide Learning. On the Horizon, 17 (2), 142-152.

- Barrett, H. (2007). Researching Electronic Portfolios and Learner Engagement: The REFLECT Initiative. Journal of Adolescent and Adult Literacy, 50 (6), 436-449.

- Barrett, H. (2006). Researching and Evaluating Digital Storytelling as a Deep Learning Tool. The Reflect Initiative. Retrieved January 18, 2014 from http://helenbarrett.com/portfolios/SITEStorytelling2006.pdf.

- Brečko, B. N. and Vehovar, V. (2008). Informacijsko-komunikacijska tehnologija pri poučevanju in učenju $v$ slovenskih šolah. Ljubljana: Pedagoški inštitut.

- Carrington, V. and Robinson, M. (2009). Digital Literacies: Social Learning and Classroom Practices. Los Angeles: Sage, London: UKLA, cop.

- Danielson, C. and Abrutyn, L. (1997). An Introduction to Using Portfolios in the Classroom. Alexandria, Virginia: ASCD.

- Davies, J. A. and Merchant, G. (2009). Web 2.0 for Schools: Learning and Social Participation. New York: Peter Lang Publishing.

- Du, H. and Wagner, K. (2007). Learning with Weblogs: Enhancing Cognitive and Social Knowledge Construction. IEEE Transactions on Professional Communication, 50 (1), 1-16.

- Hartnell Young, E. and Morriss, M. (2007). Digital Portfolios: Powerful Tools for Promoting Professional Growth and Reflection. Thousand Oaks: Corwin Press.

- Henry, J. and Jones, B. (2006). Interactive Learning Fails Reading Test. Retrieved February 20, 2014 from http://www.smh.com.au/news/technology/interactivelearning-flops/2006/01/09/1136771500779.html. Hyun, E. (2005). A Study of 5 to 6 Year Old Children's Peer Dynamics and Dialectical Learning in a Computer-Based Technology-Rich Classroom Environment. Computers \& Education, 44 (1), 69-91.

- ISTE (1998). Technology Foundation Standards for Students. Retrieved January 11, 2014 from http://www. iste.org/docs/pdfs/nets_for_students_1998_standards.pdf?sfvrsn=2.

- Kemmis, S. and McTaggart (1991). Načrtovalnik akcijskega raziskovanja. In: Kemmis, S. et al. (ed.). Kako se lotimo akcijskega raziskovanja v šoli (7-40). Radovljica: Didakta, Slovensko društvo pedagogov. 
- Kigozi Kahiigi, E. et al. (2008). Exploring the e-Learning State of Art. Electronic Journal of e-Learning, 6 (2), 77-88.

- Kim, H. N. (2008). The Phenomenon of Blogs and Theoretical Model of Blog Use in Educational Contexts. Computers \& Education, 51 (3), 1342-1352.

- Krek, J. and Vogrinc, J. (2007). Učitelj $\bigotimes$ raziskovalec vzgojno-izobraževalne prakse. In: Krek, J. et al. (ed.). Učitelj v vlogi raziskovalca: akcijsko raziskovanje na področjih medpredmetnega povezovanja in vzgojne zasnove v javni šoli (23-57). Ljubljana: Pedagoška fakulteta.

- Lapuh Bele, J. and Rugelj, J. (2007). Blended Learning - An Opportunity to Take the Best of Both Worlds. International Journal of Emerging Technologies in Learning, 2 (3), 1-5.

- Lorenzo, G. and Ittelson, J. (2005). An Overview of Eportfolios. Educause Advancement of Learning through IT Innovation Series. Retrieved February 4, 2014 from http://net.educause.edu/ir/library/pdf/eli3001.pdf.

- Marentič Požarnik, B. (2001). Uspešna prenova terja enakopravnejši položaj »alternativne« raziskovalne paradigme in učitelja raziskovalca. Sodobna pedagogika, 52 (2), 64-80.

- Razdevšek Pučko, C. (1997). Vpliv kognitivne psihologije na spremembo paradigme preverjanja in ocenjevanja znanja. Pedagoška obzorja, 6 (4), 127-141.

- Redecker, C. et al. (2009). Learning 2.0: The Impact of Web 2.0 Innovations on Education and Training in Europe. Final Report. Retrieved January 16, 2014 from http://ftp.jrc.es/EURdoc/JRC55629.pdf.

- Reynolds, N. (2000). Portfolio teaching: a guide for instructors. Boston; New York: Bedford/St. Martin's, cop.

- Roblyer, M. D. (2006). Integrating Educational Technology into Teaching. Upper Saddle River: Pearson.

- Vogrinc, J. and Valenčič Zuljan, M. (2009). Action Research in Schools-An Important Factor in Teachers' Professional Development. Educational studies, 35 (1), 53-63.

- Young, J.R. (2005). Professors Give Mix Reviews of Internet's Educational Impact. Retrieved January 14, 2014 from http://chronicle.com/article/Professors-Give-Mixed-Reviews/13019. 


\section{Шпела Кунчич,}

Основна школа „Прежихов Воранц“, Љубљана

др Цвета Раздевшек Пучко,

Педагошки факултет, Љубљана

др Јоже Ругељ,

Педагошки факултет, Љубљана

\section{ДИДАКТИЧКА ВРЕДНОСТ ВЕБ-ЛОГА У ПРВОМ ЦИКЛУСУ ОСНОВНОГ ОБРАЗОВАҢА}

У овом раду је представљена иновација у форми веб-лоїa (weblog), која се користи као подршка педагошком раду у првом циклусу основног образовања. Она је заснована на концептима двеју форми: презентације и електронског портфолија, тј. компјутерске колекције артефаката која показује шта су појединци или групе учили и проучавали током одређеног временског периода. За разлику од класичне презентације портфолија, у којој је садржај приказан у фолдерима или на папирима, веб-лог омогућава учесницима образовног процеса да креирају, складиште и приказују свој рад користећи информационокомуникационе технологије (ИКТ). Они омогућавају документовање процеса учења и

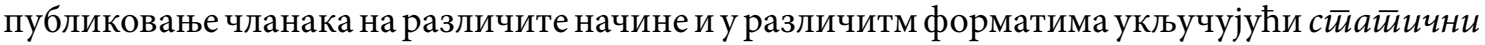

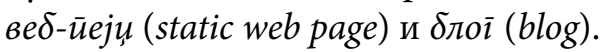

Укључивање модерног ИКТ-а у образовни систем, са акцентом на креирању и коришћењу образовног веб-лої Циљ овог истраживања био је да се истражи употреба ИКТ-а у образовању и да се представи модел за његову примену на основношколском нивоу. Уз иновирање и процењивање дидактичке вредности веб-лога, посебна пажња је дата развоју дигиталне писмености и вештинама рефлексије.

Квалитативно акционо истраживање обухватило је двадесет ученика и њихових родитеља из једног одељења деветогодишње основне школе у Љубљани, у Словенији. Истраживање је трајало три године и односило се на први циклус основношколског образовања (тј. од првог до трећег разреда) и свака година је одговарала једном акционом кораку. Акциони кораци су обухватили спирални процес и у сваком је било планирања, акције и процене постигнутих резултата (Kemmis and McTaggart, 1991; Vogrinc and Valenčič Zuljan, 2009). Учитељ је имао улогу наставника истраживача и користио је нестандардне упитнике, нестандардне семиструктурисане групне интервјуе, анализе докумената и опсервацију као методе квалитативног истраживања. Током периода развоја педагошке иновације сви кораци су били добро осмишљени и забележени, док су верификација и кредибилност резултата истраживања били поткрепљени следећим стратегијама: дуг период сакупљања података, употреба триангулације, прецизно планирање процеса истраживања, консултације и поновљене презентације резултата стручној публици. Потписана овлашћења су узета од родитеља ученика који су учествовали у истраживању, као и електронска публикација материјала коју су ученици саставили. Компјутер са одговарајућим софтвером и приступ интернету били су обезбеђени за ово истраживање. 
При првом акционом кораку креиран је портфолио у коме су били материјали у различитим електронским форматима. Али, како се прикупљањем материјал повећавао, примењен је вођен рефлексивни процес у коме су ученици критички испитивали сакупљене

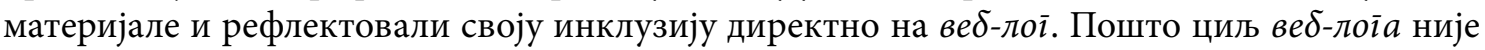

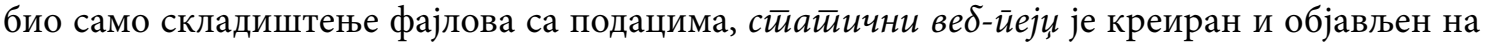
интернету. У овом процесу коришћен је известан број одговарајућих софтверских алата ради дизајнирања јасног и једноставног интерфејса, постављања хијерархијске структуре, дефинисања шеме колора и конструисања графичке шеме прилагођене нивоима знања

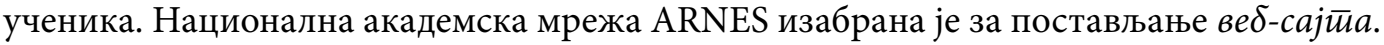

Полазна тачка за други акцијски корак била је одређена екстензивном употребом различитих ИКТ-а ради задовољавања образовних циљева и побољшавања електронске писмености. Стога, креирани веб-лої и употребљени дидактички софтвер комбиновани су са традиционалним методама поучавања за различите школске предмете. На овај начин, веб-лоі није више користио само као онлајн албум артефаката већ је све више добијао литерарну функцију. Док је претраживање нета постало део различитих активности, ученицима су представљени имејл и инстант поруке. На крају године проверили смо, посебно дизајнираном листом провере, циљева учења (NET 1998; Hyun, 2005) и да ли је достигнут ниво основне дигиталне писмености.

Појављивање блогова који сунеоспорно имали неке атрибуте веб-лоїова представљало је основу трећег акционог корака. На овом кораку направљен је ве $\delta$-логі заснован на блогу. За провајдера је изабран Edublogs, чије су услуге биле бесплатне и без комерцијалних реклама. Систем блога омогућава бржи и лакши начин хронолошки одређеног публиковања садржаја мултимедија, уз дељење одговарајућих веб-линкова (blogroll) и инклузију малих апликација (widgets). Пошто је наш циљ био да активно укључимо ученике и њихове родитеље у процес

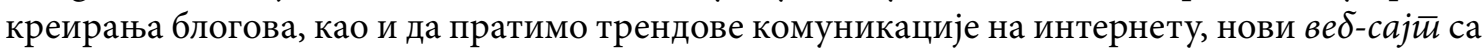
личним блоговима ученика је креиран.

Резултати акционог истраживања откривају да одговарајућа употреба савремених образовних технологија осавремењује традиционални начин поучавања и омогућује ученицима да стичу веће и шире знање. Изгледа да рационална употреба педагошких иновација може да буде мотивационо оруђе у поучавању, омогућавајући ученицима да постигну образовне циљеве, развију дигиталну писменост и стимулишу критичку рефлексију. Штавише, помаже ученицима да постану свесни процеса учења и напредовања током одређеног времена. Узимајући у обзир све ово, резултати истраживања трију акционих корака откривају да образовање, засновано на ИКТ-у, може само да буде додатак традиционалном начину поучавања. Али упркос свим ограничењима, модерна оруђа и сервиси чине ефикасну допуну класичном образовању отварањем простора за показивањем индивидуалних вештина, способности и компетенција за доживотно учење. Са друге стране, знање које се стекло током овог истраживања, уз бројна позитивна открића и повратну информацију учесника, представља солидну базу за даља истраживања и образовну праксу.

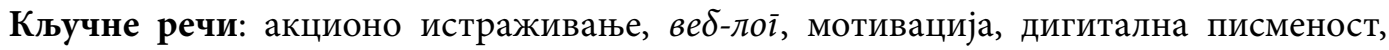
рефлексија. 